\section{OClinitall atotes:}

\section{MEDICAL, SURGICAL, OBSTETRICAL, AND THERAPEUTICAL.}

\section{POTT'S FRACTURE BY DIRECT VIOLENOE.} By W. N. ClemmeY, M.R.C.S. \&C.

A MAN fifty years of age was admitted to the Bootle Borough Hospital on Nov. 7th, under the care of Mr. Wills. He had been working at the docks lifting iron bars, each weighing about $5 \mathrm{cwt}$, off a pile $4 \mathrm{ft}$. in height. He was standing close to the pile when one of the bars, accidentally loosened, fell to the ground, striking his right leg a few inches above the onter ankle, throwing him on his left side and pinning his right foot under him. When examined, bruising was noticed on the outer side of the leg at the point where the patient said he was struck, the ankle-joint being swollen, especially on the inner side; the foot was displaced outwards and slightly backwards, the fibula broken $2 \frac{1}{2}$ in. above the tip of the external malleolus, and the end of the internal malleolus broken off-in fact, the condition known as Pott's fracture. The interest in this case is that the cause of the fracture is very rare, the same result being brought about by the direct violence of the bar striking the leg on the outer side just above the ankle as usually follows the indirect violence of the well-known street ankle-twist. The patient himself was very emphatic in the statement that the bone broke at the moment the bar struck him, and not owing to any attempt on his part to raise himself from the ground, the bruising found above the ankle on the outer side adding confirmation to this. Bootle.

H EMOGLOBINURIA IN A CHILD EIGHT YEARS OF AGE, PROBABLY DUE TO THE INHALATION OF SEWER AIR.

By Gordon Sharp, M.B. EdiN., AND

\section{WilliaM SUMmerskill, M.R.C.S.ENG., L.R.C.P.,LoND.}

CASES of hæmoglobinuria are so comparatively rare that we have thought fit to put upon record the following case which occurred in our practice.

The patient, a girl eight years of age, in comfortable circumstances, had previously enjoyed good health, and there was no history of a previous similar attack. When first seen she was suffering from dyspncea, her face was puffy and she frequently had a desire to micturate, but six ounces of urine only were passed in the twenty-four hours. The onset of symptoms was rapid, the child having been quite well two days previously. At first the case was diagnosed as acute Bright's disease, although there was an absence of the "Bright" eye, a sign which has been called attention to more especially by Professor Grainger Stewart. The dyspnœa was thought to be due to uræmia, and it was only after the urine was examined chemically and microscopically that the true nature of the disease was discovered. The urine was chocolate-brown in colour and contained a coffee-brown sediment. When it was heated this brown sediment rose to the surface, giving a clue to the disorder that we had to deal with, for hæmoglobin rises to the top when heated in a fluid, while coagulated blood cells fall to the bottom. On applying the guaiacum and ozonic ether test a blue colour was at once struck, showing the presence of bæmoglobin in some form or other. The microscope revealed no casts, only a few red cells entire, but the field was covered with masses of amorphous hæmoglobin. A few red cells with the bæmoglobin partly extruded, some transitional epithelium, and crystals of calcium oxalate were also seen. The absence of casts, the comparative absence of red blood cells, and the presence of a large amount of hæmoglobin made the diagnosis certain. The acute symptoms soon subsided, the patient being convalescent in three days after the onset of the illness, although she was in a very anæmic condition. Day by day the urine was examined for casts, but none were found. A trace, but only a trace, of albumen was detected up to the eleventh day, after which the urine was normal. The hæmo- globin disappeared entirely after the fourth day. The treatment consisted in administering four-minim doses of tincture of digitalis four times a day till the dyspnœa disappeared. which it did by the end of the second day. The intention was to produce diuresis and to strengthen the heart. Milk diet, diluents, warmth, and the recumbent posture were enjoined. The latter was necessary, for on one occasion, when the patient disobeyed orders and sat up, she fainted, most likely owing to the anæmia. After the brown sediment of hæmoglobin had disappearea from the urine and a larger amount of urine was being passec] the digitalis was stopped, and three-minim doses of Towler's. arsenical solution were given four times daily, and in a day or two the anæmia disappeared and the child became quite rosy.

The cause of the disease is obscure, but the watercloset pipes of the house had been leaking for a few weeks and a disagreeable smell was perceived, and at the time of the attack the leaking pipes were being taken up and replaced by sound ones, the smell being more than ordinarily disagreeable. It is possible that the inhalation of sewer air was the: cause of the rapid and severe disintegration of the blood cells, for sewer air readily affects young children, and noxious, vapours cause hæmoglobinuria, although, as far as we are: aware, no case has as yet been traced to the inhalation of sewer emanations.

Meanwood-road, Leeds.

\section{9 ettirtor}

\section{HOSPITAL PRACTICE, BRITISH AND FOREIGN.}

Nulla autem estalia pro certo noscendi via, nisi quamplurimas et moz borum et dissectionum historias, tum aliorum tum proprias collecta habere, et inter se comparare.-MorgagNI De Sed. et Cans. Morb., lib. iv. Procmium.

\section{ST. THOMAS'S HOSPITAL.}

TWO CASES OF CASAREAN SECTION IN DEFORMED TEEYTE RECOVERY OF MOTHERS AND CHILDREN.

(Under the care of Dr. C. J. CULlingworta)

In The Lancet of Dec. 2nd we gave the notes of a casa in which the operation of Cresarean section was performect in a case of cancer of the cervix uteri. This week we publish notes of two cases in which the operation was performed for contracted pelvis, the estimated true conjugate measurement in the first being $2 \frac{5}{8} \mathrm{in}$., and in the second the pelvis was small in all its dimensions. In a discussion on this subject before the Obstetrical Society, Dr. Cullingworth is reportec to have said : "If a vote were taken, all obstetricians would agree that the patient should be advised to undergo Cæesarear. section if the conjugate diameter was $2 \frac{1}{2} \mathrm{in}$. or under. The majority would most likely be in favour of giving that advice where the conjugate did not exceed $2 \frac{1}{2}$ in. ; whilst a large minority would be disposed to recommend Cæsarean section under such circumstances if the contraction was even as considerable as $2 \frac{3}{4}$ in. He himself would be found in the last category." At the same meeting it was stated that the maternal mortality after the operation of craniotomy was 66 per cent. and after Cæsarean section 8.8 per cent., whilst in the latter the infant mortality was nil.

CASE 1. Casarean section in a case of flattened pelvis: recovery of mother and child. (From the notes of Mr. C. $s$. Wallace and Mr. P. Northcote.) - A woman thirty.one years of age was admitted to St. Thomas's Hospital on Jan. 28th of this year, in the ninth month of her seventh pregnancy, with a view to having the operation of Cæsarean section performed ir. the course of a few days. She had suffered from rickets as a child, and did not begin to walk until four years of age. The catamenia commenced at the age of fifteen, and were regular. She was married on Jan. 31st, 1885. Her first child was born at full term on Oct. 30 th, 1885 . Craniotomy was performed at her own house, and she was in bed for two months afterwards. She again became pregnant at the end of 1886 . Labour was induced at the end of seven months, no instruments being used. The child only survired its birth a few hours. Her third pregnancy terminated spontaneously in 